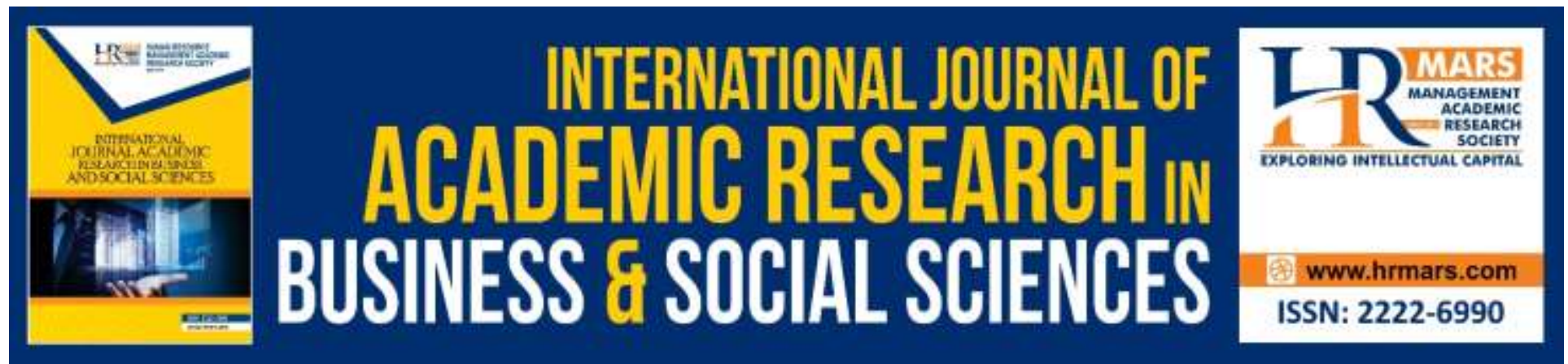

\title{
Perception of Employers' Children towards Domestic Helpers
}

\author{
Nurul Nadia Abd Aziz
}

To Link this Article: http://dx.doi.org/10.6007/IJARBSS/v8-i5/4173

DOI:10.6007/IJARBSS/v8-i5/4173

Received: 24 April 2018, Revised: 14 May 2018, Accepted: 29 May 2018

Published Online: 04 June 2018

In-Text Citation: (Aziz, 2018)

To Cite this Article: Aziz, N. N. A. (2018). Perception of Employers' Children towards Domestic Helpers. International Journal of Academic Research in Business and Social Sciences, 8(5), 720-732.

Copyright: (C) 2018 The Author(s)

Published by Human Resource Management Academic Research Society (www.hrmars.com)

This article is published under the Creative Commons Attribution (CC BY 4.0) license. Anyone may reproduce, distribute, translate and create derivative works of this article (for both commercial and non-commercial purposes), subject to full attribution to the original publication and authors. The full terms of this license may be seen at: http://creativecommons.org/licences/by/4.0/legalcode

Vol. 8, No. 5, May 2018, Pg. 720 - 732

http://hrmars.com/index.php/pages/detail/IJARBSS

JOURNAL HOMEPAGE

Full Terms \& Conditions of access and use can be found at http://hrmars.com/index.php/pages/detail/publication-ethics 


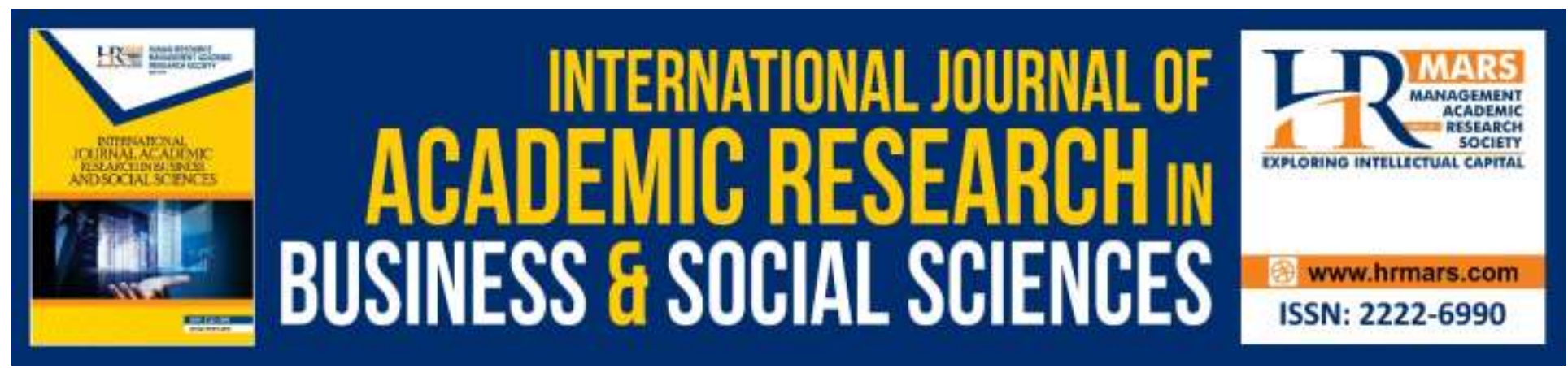

\title{
Perception of Employers' Children towards Domestic Helpers
}

\author{
Nurul Nadia Abd Aziz \\ Faculty of Business Management, Universiti Teknologi MARA Pahang Raub Campus, Pahang, \\ Malaysia
}

\begin{abstract}
Numerous studies were carried out over the years on domestic helpers have focused on the employers' perspectives. Very little research however, has been conducted to investigate the perception of domestic help among the employers' children. Therefore, in this study, we aimed to have a clear perspective of the situation by analyzing the perception of employers' children towards their domestic helpers. Three main issues were highlighted in this study: the relationship between the children and the domestic helpers, the opportunity costs of having domestic helpers, and the parental roles that should not be handed over to the domestic helpers. Additionally, this study explored the characteristics of domestic helpers favoured and unfavoured by the employers' children. The primary data were collected via in-depth interviews and informal conversations with 13 adolescents aged between 18 and 20, whose full-time domestic helpers live within their households. The key finding of this study proved that the presence of household helpers had no significant impact on the relationship between the children and their parents or siblings. Also, the results indicated that domestic helpers should not be responsible in caring for their employers' younger children, cooking and managing matters related to the children's education.
\end{abstract}

Keywords: Domestic Helpers, Employers' Children, Parental Roles, Perception.

\section{Introduction}

The presence of domestic helpers may have a positive influence on their employers' children. For instance, the children can experience cultural enrichment by learning the language of their helpers who are likely to come from a different cultural background (Jabbar, 2014). In a study conducted by Roumani (2005), parents expressed their concerns about the potential cultural and religious influences domestic helpers may have on their children's language development. Nevertheless, the cultural and religious differences were more often associated with benefit than harm to their children. More importantly, having a helper improved the children's communication skills. Because of the opportunity of foreign language exposure, employers reportedly admitted to retaining their highly educated Filipino and Thai domestic 
helpers who use English as a medium of communication with children. This decision provided the much-needed home intervention for children to communicate in English on a daily basis (Frantz, 2008; Lan, 2010; Leung, 2012). Some researchers fairly pointed out that the presence of a domestic helper within a household may even increase children's social skills. In some way or the other, having an additional adult to interact with most days is what makes the children polite communicators with older people (Ip, Cheung, McBride-Chang, \& Chang, 2008). Additionally, when domestic helpers enter the household, the results can be a life-changing prospect for the working parents. When the household chores are taken care of by the domestic helpers, working mothers will likely have more time for themselves, and if history is any guide, they will find quality time in a day to spend with their children (Frantz, 2008).

Evidently, despite the various advantages of household help, most study respondents were employers. Previous scholars (Frantz, 2008; Lan, 2010; Leung, 2012) had only addressed the issue from the perspective of parents. Some scholars (Coren, Ward, \& Enns, 1994) however, mentioned that human perception is influenced by cognitive processing of different personality and view stimulus from within an environment. In other words, your own knowledge, imagination and expectation of the environment influences your perception (Hussin \& Taibi, 2007). Bear in mind that, parents and children may have different perceptions about household help.

Parents earn respect from domestic helpers for being the employers. The employer's children, on the other hand, are often regarded by the helpers as those who need care and protection, like their own biological children (Paitoonpong, 2002). It's a good idea to understand the differences in the type of services rendered by the domestic helpers to their employers and their employers' children. This general principle indirectly illustrated that employers and children have different experiences and perceptions towards household help. Therefore, another thing that may be worth investigating further, as recommended by some researchers (Hussin \& Taibi, 2007), include children's perception towards household help for the purpose of social formation of the Malaysian society. Thus, this research sought to explore the perception of employers' children towards their domestic helpers. It is hoped that this study will allow researchers to close the information gap and benefit from the potential appreciation of the presence of domestic help in the lives of children.

\section{Literature Review}

Based on reports from the Malaysian Ministry of Human Resources, foreign domestic helpers in Malaysia came from 13 countries around the world (Bernama, 2016). In 2016, there was a total of 143,617 foreign domestic helpers in Malaysia, out of which 96,375 (67\%) were from Indonesia. As represented by previous findings, Indonesian maids are comfortable working with Malaysian employers due to similarities in terms of culture, religion and language (Hussin \& Taibi, 2007; Maksum \& Surwandono, 2017). This finding is important because domestic helpers often live in the same premises as their employers (Chan, 2005; Shah, Badr, \& Shah, 2012; Tang \& Yung, 2016).

There were many cases where both parties have had a high level of compatibility that caused work contracts to be continuously renewed. If this condition summed up contentment, employers and domestic helpers could be sharing premises for many years and treating each other like family (Cheung \& Mok, 1998; Greenfield, Flores, Davis, \& Salimkhan, 2008). Domestic 
helpers who were treated like part of the family, were usually allowed to eat together with their employers during meal times at home or in restaurants (Groves \& Lui, 2012). Employers who treated their helpers like family would deliberately avoid the use of direct instructions and would praise them for jobs well done (Kwan \& Dunworth, 2016). In cases where domestic helpers were regarded as paid workers (Cheung \& Mok, 1998; Huang \& Yeoh, 1996), treatments usually involved formal relationships where the employers did not engage in friendly conversations or meal times together with the helpers.

The effects of household help have received much scholarly attention, with three research streams conducted within this category. One stream of research related to the impact of domestic helpers on working women (Frantz, 2008; Groves \& Lui, 2012; Lan, 2003). Some qualitative studies reported that the presence of maids may increase women's leisure time, reduce strain among married working women and facilitate the life of the host families (Colombo, 2007; Frantz, 2008; Leong, 2011; Luk \& Shaffer, 2005; Shah et al., 2012). On the contrary, some studies reported that the presence of maids may increase the burden of women because of the "less-than-optimal" work quality done by the maids (de Regt, 2008; Frantz, 2008; Fu \& Shaffer, 2001; Groves \& Lui, 2012; Mindarti \& Buang, 2012; Näre, 2008).

The second stream explored the effects of domestic helpers on the lives of elderly people (Chong, Kwan, Chi, Lou, \& Leung, 2014; Shah et al., 2012). Some studies found that the presence of a domestic helper may moderate the effects of stressors among spousal caregivers (Chong et al., 2014). In other words, assistance from a domestic helper may reduce the negative effects of some stressors on the well-being of frail elders and spousal caregivers. A study done by Shah and his colleagues in 2012, found that due to the changing trends in Kuwait, many women were seen working outside their homes which consequently offered potential work opportunities for domestic helpers to be hired as caretakers of elderly parents or parent-in-laws. The aforementioned studies indicated that domestic helpers may provide coping and social support without neglecting the family as a major role in the care of elderly people (Chong et al., 2014; Shah et al., 2012).

The third stream of research focused on the effects of the presence of domestic helpers on children (Chan, 2005; Cheo \& Quah, 2005; Ip et al., 2008; Tang \& Yung, 2016; Tse et al., 2009). A study conducted in Hong Kong (Tang \& Yung, 2016) found that the presence of Filipino maids had an impact on the academic achievement of children, which significantly influenced their high scores in English subjects, but not in Chinese and Mathematics subjects. Indonesian maids, however, were found to have a slightly significant impact on the children's achievement in these three subjects. The same study concluded that the English speaking skills of Filipino maids had contributed significantly to the academic achievement of children in Hong Kong. This last stream is undergoing more research and development, leaving scholars constantly searching for the effects of household help on children's attitude (Dulay, Tong, \& McBride, 2017; Greenfield et al., 2008; Ip \& Cheung, 2008; Leung, 2012). Despite the accumulation of knowledge, it has been forecast that these studies will again focus on the perception of parents, not their children. Hence, in this paper, we looked into the the effects of household help from the eyes of the employers' children. 


\section{Methodology}

This study was conducted at the exploratory stage using a qualitative approach. Hence, the findings were not conclusive and could only be used as the foundation for larger-scale studies in the future. A snowball sampling was used whereby thirteen students from the university where the author was teaching at the time of the research, were recruited. The data were collected via open-ended interviews with the adolescents living with their domestic helpers. To ensure confidentiality, the real names of the respondents were concealed and coded as Respondent 1 to Respondent 13. A structured questionnaire was used for the interviews, which included a question on the types of relationship between the respondents and the domestic helpers (either as an employer-employee relationship or as part of a family member). Other questions were related to whether the adolescents were closer to their domestic helper or their parents and siblings; the opportunity cost of having a domestic helper; and the parental roles that should not be handed over to the domestic helpers.

\section{Results and Discussions \\ Respondents' Profile}

Table 1 showed the demographic characteristics of the thirteen respondents interviewed in this study. Based on the descriptive analysis, the majority of the respondents were females. In addition, all the respondents were students of a public university in the 18-20 age range. Twelve of the interviewees had full-time domestic helpers. Out of which, eleven of them were Indonesians and one had a part-time Malaysian domestic helper. Only two respondents employed Malaysian domestic helpers while the rest employed Indonesian helpers. The youngest domestic helper was 23 years old whereas the oldest was 55 years old.

Table 1: Demographic Profile of Respondents

\begin{tabular}{|c|c|c|c|c|c|c|c|}
\hline Respondents & Gender & Age & $\begin{array}{l}\text { Domestic } \\
\text { helpers' } \\
\text { country of } \\
\text { origin }\end{array}$ & $\begin{array}{c}\text { Domestic } \\
\text { helper's } \\
\text { age }\end{array}$ & $\begin{array}{l}\text { How many } \\
\text { domestic } \\
\text { helpers } \\
\text { your family } \\
\text { has ever } \\
\text { taken? }\end{array}$ & $\begin{array}{l}\text { Length of } \\
\text { time she } \\
\text { works with } \\
\text { your family } \\
\text { (current } \\
\text { domestic } \\
\text { helper) }\end{array}$ & $\begin{array}{c}\text { What do } \\
\text { you call } \\
\text { your } \\
\text { domestic } \\
\text { helper? }\end{array}$ \\
\hline 1 & Female & 20 & Indonesia & 26 & 1 & 7 years & Kakak \\
\hline 2 & Female & 20 & Indonesia & 40 & 1 & 10 years & Bibi \\
\hline 3 & Female & 20 & Malaysia & 40 & 2 & 8 years & Auntie \\
\hline 4 & Male & 18 & Indonesia & 40 & 5 & 4 years & Bibi \\
\hline 5 & Female & 20 & Indonesia & 47 & 8 & 3 years & Bibi \\
\hline 6 & Female & 19 & Indonesia & 39 & 4 & 2 years & Bibi \\
\hline 7 & Female & 20 & Malaysia & 55 & 2 & 1 years & Tante \\
\hline 8 & Female & 20 & Indonesia & 23 & 10 & 6 mths & Kakak \\
\hline 9 & Male & 18 & Indonesia & 30 & 1 & 13 years & Kakak \\
\hline 10 & Female & 18 & Indonesia & 46 & 8 & 3 years & Bibi \\
\hline 11 & Male & 20 & Indonesia & 45 & 2 & 5 years & Bibi \\
\hline 12 & Male & 18 & Indonesia & 40 & 2 & 1 years & Bibi \\
\hline 13 & Female & 20 & Indonesia & 46 & 3 & 9 years & Bibi \\
\hline
\end{tabular}

Three respondents had their domestic helpers for a long period ranging from seven to thirteen years. Respondent 13 had three domestic helpers in which the last one served for nine 
years. Respondents 5 and 10 had eight domestic helpers with the latest domestic helper having been working for a period of three years. Respondent 8 had the highest number of domestic helpers (ten) with the latest domestic helper having been working for six months. Nine respondents called their domestic helpers bibi and tante, which mean auntie in the Indonesian language. Only three respondents called their helpers kakak, which means sister.

\section{Characteristics of Domestic Helpers as Highlighted by Employers' Children}

Table 2 showed the characteristics of domestic helpers favoured and unfavoured by the employers' children. These perceptions are important to provide an overview of the characteristics of the domestic helpers in Malaysia. The feature most favoured by the employers' children was the religious practice of the domestic helpers (mentioned by 9 respondents). On the contrary, not covering their aurat, which means not covering the whole body perfectly and not wearing a scarf (hijab), was the most unfavourable characteristic of the domestic helpers (mentioned by 4 respondents). These findings were in line with the previous study (Aziz, Ismail, \& Samad, 2014; Frantz, 2008), which reported that even though the employers may not be highly religious, they would prefer the domestic helper to adhere to their religion.

Table 2: Characteristics of domestic helpers as highlighted by employers' children

\begin{tabular}{|l|l|l|}
\hline \multirow{5}{*}{ Favoured } & $\begin{array}{l}\text { Characteristics of domestic helpers as } \\
\text { mentioned } \\
\text { by thirteen respondents }\end{array}$ & $\begin{array}{l}\text { Frequency of being } \\
\text { mentioned by employers' } \\
\text { children }\end{array}$ \\
\cline { 2 - 3 } & Religious practice - Muslim, pray, fear of God & 9 \\
\cline { 2 - 3 } & Hardworking, diligent & 9 \\
\cline { 2 - 3 } & Warm-hearted, loving, friendly & 8 \\
\cline { 2 - 3 } & Responsible, committed to work & 8 \\
\cline { 2 - 3 } & Respectful, courteous, polite & 6 \\
\cline { 2 - 3 } & Trustworthy, reliable, honest, frank, \\
& dependability & 5 \\
\cline { 2 - 3 } & Obedient & 4 \\
\cline { 2 - 3 } & Cheerful, humorous & 4 \\
\cline { 2 - 3 } & Hygienic & 2 \\
\cline { 2 - 3 } & Easy to accept criticism & 1 \\
\cline { 2 - 3 } & Work discipline & 1 \\
\hline Unfavoured & Disobedient to religion & 4 \\
\cline { 2 - 3 } & Less hygienic & 4 \\
\cline { 2 - 3 } & Being idle due to cell phone or television & 2 \\
\cline { 2 - 3 } & Hard to understand instructions & 2 \\
\cline { 2 - 3 } & Showing protest & 1 \\
\cline { 2 - 3 } & Extreme curiosity & 1 \\
\cline { 2 - 3 } & Often mocking the children & 1 \\
\cline { 2 - 3 } & Nagging in her native language & 1 \\
\cline { 2 - 3 } & Waking up late & \\
\cline { 2 - 3 } & Does not perform the work as directed & 1 \\
\hline & & \\
\hline
\end{tabular}


INTERNATIONAL JOURNAL OF ACADEMIC RESEARCH IN BUSINESS AND SOCIAL SCIENCES Vol. 8, No. 5, May 2018, E-ISSN: 2222-6990@ 2018 HRMARS

\begin{tabular}{|l|l|l|}
\hline & Slightly rough & 1 \\
\cline { 2 - 3 } & Entering the bedroom without permission & 1 \\
\cline { 2 - 3 } & Grumpy & 1 \\
\cline { 2 - 3 } & Spreading gossip to outsiders & 1 \\
\cline { 2 - 3 } & Too friendly & 1 \\
\cline { 2 - 3 } & Absent-minded & 1 \\
\cline { 2 - 3 } & $\begin{array}{l}\text { Prone to blackmailing, extortion to report } \\
\text { misconduct to parents }\end{array}$ & 1 \\
\hline
\end{tabular}

Other favourable features of domestic helpers were hardworking and diligent (mentioned by 9 respondents); warm-hearted, loving, and friendly (mentioned by 8 respondents); responsible and committed to work (mentioned by 8 respondents); respectful, courteous, and polite (mentioned by 6 respondents); trustworthy, reliable, honest, frank, and dependability (mentioned by 5 respondents); obedient (mentioned by 4 respondents); and cheerful and humorous (mentioned by 4 respondents). In contrast, the unfavourable features were less hygienic (mentioned by 4 respondents); being idle due to the cell phone or television (mentioned by 2 respondents); and hard to understand instruction (mentioned by 2 respondents).

\section{The Relationship between Employers' Children and Domestic Helpers}

Based on the findings, the presence of domestic helpers had no significant effect on the intimate relationship of the children with their parents and siblings. Despite the long staying period of the domestic helpers with the host family, the children claimed to still feel close to their family members (Respondents 1, 2, 3, 5, 6, 7, 8, 9, 10, and 11). Only one respondent (Respondent 4) claimed to feel closer to the domestic helper than to his own parents. Meanwhile, two respondents (Respondents 4 and 6) claimed to feel closer to the domestic helper than to their siblings.

The good rapport between Respondent 4 and his domestic helper could be explained by the inability of the working parents to give an immediate response to the children's needs as they are away from home most of the time during the day (Ip et al., 2008). On the other hand, the domestic helper is always at home and therefore, able to provide more attention to the children. Roumani (2005) suggested that working parents should allocate quality time for their children no matter how tired they are and regardless of the amount of time they spend outside their home. This behaviour is necessary to redefine the bonding time of the parents with their children.

When the respondents were asked to describe their relationship with their domestic helpers, only a few respondents classified their relationship with the domestic helper as an employer-employee relationship (Respondents 3, 4 and 10). Meanwhile, most respondents considered their domestic helpers as part of their family (Respondent 1, 2, 5, 6, 7, 8, 9, and 11). This type of relationship matched their parents' relationship with the domestic helpers, except for Respondent 1 . These findings were consistent with the previous study (Moras, 2009) whereby most employers neither considered their home as a workplace nor regarded themselves as employers. It was further argued that regarding a domestic helper as "one of the family 
members" could provide an opportunity for the employers to exploit their domestic helpers and conceal the power relationship at work.

\section{Opportunity Cost of Having a Domestic Helper}

This section discussed the opportunity costs of having a live-in domestic helper. The majority of the respondents claimed to have no privacy (Respondents 2, 4, 5, 7, 8, 10, and 11). In fact, Respondent 13 said that not only did she lose her privacy but she was also required to share her room with the domestic helper. Respondents 9, 11, and 12 (all were male respondents) reported feeling embarrassed for not wearing clothes in their own house. In fact, they also claimed to feel awkward if they had to stay at home alone with the domestic helper. Furthermore, Respondent 1 said that she was uncomfortable talking to her family. Respondent 9 claimed to feel uncomfortable especially during a family conflict in the presence of the domestic helper. These findings were in line with the findings of the previous research which stated that outsourcing could potentially result in the loss of a family's privacy (Baxter, Hewitt, \& Western, 2009; Cortés \& Pan, 2013; Ruijter \& Lippe, 2015; van der Lippe, Frey, \& Tsvetkova, 2013).

In addition, Respondents 7 and 9 encountered difficulties when planning for a vacation. Respondent 7 argued that:

"Our cars are small and can just fit our family, so how can we bring a maid together? My dad did not believe in leaving the maid at home alone. So, one of us had to stay at home with the maid while the others went on vacation. During Hari Raya, my father had to travel twice to transport the whole family members back to the village. Fortunately, my brother already has a driving license, so nobody needs to be left at home. We can travel with two cars".

Meanwhile, Respondent 9 said that the helper has been staying with his family for 13 years and the helper has never been left alone at home throughout her stay. She is taken wherever to go, including dining at a restaurant and going on a holiday abroad. These findings supported a previous study which highlighted that domestic helpers are often pampered and regarded as part of the family by their employers, resulting in them often joining the host family for vacations (Lee, 2016).

Moreover, the respondents reported being frequently asked by their parents to keep an eye on the domestic helpers, which is perceived by them as an additional task. Respondent 1,8 , and 10 emphasized that despite considering the domestic helper as part of the family, the domestic helper is, after all, a stranger and therefore, cannot be fully trusted. Many respondents said that they have to remain vigilant and take care of their valuables items. Nine respondents (Respondents 3, 4, 6, 7, 8, 9, 10, 12, and 13) mentioned that their parents often warn them to keep their valuable items such as wallets and jewelry in a hidden place. Respondent 11 (male, 20 years old) said:

"...My dad always reminds me to always be at home and keep an eye on the maid. He also often warns me to keep my money in a very hidden place". 
Only Respondent 3 had no opportunity cost because the domestic helper does not stay with the family but visits the house on a daily basis to complete some tasks.

\section{Parental Roles that Should Not be Handed to Domestic Helpers}

Parents often hire a domestic helper to manage the household chores and the children (Hussin \& Taibi, 2007) but the adolescents may have their own perception of the parental roles that should not be handed over to the domestic helpers. Respondents 1 and 8 perceived that the task of caring for infants and young children should not be left to the domestic helpers. Respondent 8 stated that:

"Parents should not give full confidence to the maid in taking care of young children. This is to prevent children from being abused by the maid. After all, these are precious moments for parents to give them the best education including religious education when they are still young, right?"

The uneasy feeling about the care of young children by the domestic helpers was also shared by Respondent 9 (18 years old), who has a domestic helper who has been with his family since he was 5 years old:

"Normally a long-serving maid will be entrusted with the care of young children. This is up to the employers. If they believe in the maid, it should be fine. But what I noticed is that if young children are used to being fully taken care of by a maid, they will be closer to the maid than their own parents. For example, my little sister, she was taken care of by the maid since she was a baby. So she is closer to the maid than my mom. So I feel like our maid knows more about her than my mom. For instance, when she cries, kakak knows how to make her stop crying better than my mom. This will cause depression to my parents when the maid takes her annual leave to return to Indonesia".

In addition to Respondents 1,8 , and 9, some other respondents also believed that the care of children should not be handed over to the domestic helpers (Respondents 2, 3, 4, 5, 6, 7, 10, and 11). Respondent 4 said that it is outrageous if the task of taking care of children is handed over to the domestic helpers while the parent goes on vacation. Furthermore, Respondents 7, 9, and 10 were in the view that it is improper for the domestic helpers to handle the children's schooling matters, such as attending the school sports event or prize giving ceremony. These findings were consistent with a previous research which emphasized that attending school occasions, reading bedtime stories, and preparing meals at family gatherings are among the parental roles that imply good parents (Chan, 2005) and therefore should not be done by the domestic helpers.

In addition to childcare, the employers' children opined that cooking should not be handed entirely to the domestic helpers (Respondents $5,6,7,9,10$, and 13). In fact, one of the 
respondents admitted that although her domestic helper is very good at cooking, she prefers to eat food that is cooked by her mother. Respondent 13 (female, 20 years old) said:

"...It does not matter if a maid is asked to prepare the ingredients for cooking or tidying the kitchen and sink after cooking, but the cooking task should be done by the mother. People say mother's cooking is the most delicious meal in the world. So I feel like a loser when I have to eat meals cooked by a maid every day, and I also miss those happy moments in the kitchen with my mom".

In summary, most respondents perceived that the domestic helpers should not undertake the tasks of caring for the young children, cooking for the family, and managing the children's school-related affairs as they are important responsibilities of the parents.

\section{Conclusion and Recommendations}

This study was conducted to measure the perceptions of employers' children toward their domestic helpers. Based on the results of the study, the majority of the respondents had a close relationship with their domestic helpers and treated them as part of their family. Nevertheless, it was demonstrated that this type of relationship had no significant impact on the close relationship of the children with their parents and siblings. In the meantime, the parents were still cautious with the domestic helpers, reminding their children to stay vigilant and to keep their valuable items in hidden places.

Parents should understand the influence of the presence of domestic helpers on the lives of their children before hiring a domestic helper. The findings of this study demonstrated that having a domestic helper living in the employer's house may invade the privacy of the employer's children. Some researchers (Ruijter \& Lippe, 2015) claimed that the privacy invasion by the domestic helpers can occur in two main ways: (1) a domestic helper staying in the house of a host family even in the absence of any family members; and (2) a domestic helper taking over tasks which are of special value for a family, such as caring for the young children. In addition, being religious was the most favourable feature of the domestic helpers among the respondents. The host family should hire a domestic helper who is religious because it has been said that people who believe in God are less like to misconduct themselves due to religious principles (Frantz, 2008).

Furthermore, the findings of this study could guide the parents in understanding the importance of their roles in certain tasks that should not be handed over to the domestic helpers. This knowledge is important to ensure a close relationship between the parents and the children and to ensure that the children do not feel neglected. As revealed by this study, children claimed that parents should not entirely delegate childcare to the domestic helpers, especially those related to the children's schooling. These findings were in line with a previous study (van der Lippe et al., 2013), whereby the education and well-being of children have special values in a family and should not be interfered by the outsiders. In essence, it is imperative for the parents to appreciate their parenting roles in the social and emotional development of their children (Roumani, 2005) before they decide to hire a domestic helper. 
This study had some limitations. Firstly, this exploratory analysis focused only on the employers' children aged between 18 and 20 years and not the younger children. Nevertheless, this study explored the adolescents' experience of living with their domestic helpers since young, which indirectly considered the views of the younger children. Secondly, due to the exploratory nature of this study which used a relatively small sample size, the results must be interpreted with caution. It is recommended to replicate this study using a larger sample size to provide more reliable findings related to the perceptions of employers' children toward their domestic helpers.

\section{References}

Aziz, N. N. A., Ismail, I. R., \& Samad, S. (2014). Developing Scale of Maid for Assessing Malaysian Employers Perception towards Quality of Maid. In Proceedings of the International Conference on Human Resource Management and Organization Effectiveness In Asia Pacific (pp. 199-208).

Baxter, J., Hewitt, B., \& Western, M. (2009). Who uses paid domestic labor in Australia? Choice and constraint in hiring household help. Feminist Economics, 15(1), 1-26.

Bernama. (2016). 143,617 pembantu rumah asing di Malaysia [143,617 foreign maids in Malaysia]. Utusan Online. Retrieved from http://www.utusan.com.my/

Chan, A. H. N. (2005). Live-in foreign domestic workers and their impact on Hong Kong's middle class families. Journal of Family and Economic Issues, 26(4), 509-528.

Cheo, R., \& Quah, E. (2005). Mothers, Maids and Tutors: An Empirical Evaluation of their Effect on Children's Academic Grades in Singapore. Education Economics, 13(3), 269-285. http://doi.org/10.1080/09645290500073746

Cheung, D. S., \& Mok, B. H. (1998). How Filipina Maids Are Treated in Hong Kong - A Comparison Between Chinese and Western Employers. Social Justice Research, 11(2), 173192.

Chong, A. M. L., Kwan, C. W., Chi, I., Lou, V. W. Q., \& Leung, A. Y. M. (2014). Domestic helpers as moderators of spousal caregiver distress. Journals of Gerontology - Series B Psychological Sciences and Social Sciences, 69(6), 966-972. http://doi.org/10.1093/geronb/gbu034

Colombo, A. D. (2007). "They call me a housekeeper, but I do everything." Who are domestic workers today in Italy and what do they do? Journal of Modern Italian Studies, 12(2), 207237.

Coren, S., Ward, L. M., \& Enns, J. T. (1994). Sensation \& Perception. (4th Editio). New York: Harcourt Brace.

Cortés, P., \& Pan, J. (2013). Outsourcing Household Production: Foreign Domestic Workers and Native Labor Supply in Hong Kong. Journal of Labor Economics, 31(2), 327-371.

De Regt, M. (2008). High in the Hierarchy, Rich in Diversity. Critical Asian Studies, 40(4), 587608.

Dulay, K. M., Tong, X., \& McBride, C. (2017). The Role of Foreign Domestic Helpers in Hong Kong Chinese Children's English and Chinese Skills: A Longitudinal Study. Language Learning, 67(2), 321-347. http://doi.org/10.1111/lang.12222

Frantz, E. (2008). of Maids and Madams: Sri Lankan Domestic Workers and their employers in Jordan. Critical Asian Studies, 40(4), 609-638.

Fu, C. K., \& Shaffer, M. A. (2001). The tug of work and family: Direct and indirect domain- 
INTERNATIONAL JOURNAL OF ACADEMIC RESEARCH IN BUSINESS AND SOCIAL SCIENCES

Vol. 8, No. 5, May 2018, E-ISSN: 2222-6990 @ 2018 HRMARS

specific determinants of work-family conflict. Personnel Review, 30(5), 502-522.

Greenfield, P. M., Flores, A., Davis, H., \& Salimkhan, G. (2008). What happens when parents and nannies come from different cultures? Comparing the caregiving belief systems of nannies and their employers. Journal of Applied Developmental Psychology, 29(4), 326-336. http://doi.org/10.1016/j.appdev.2008.04.002

Groves, J. M., \& Lui, L. (2012). The "Gift" of Help: Domestic Helpers and the Maintenance of Hierarchy in the Household Division of Labour. Sociology, 46(1), 57-73.

Huang, S., \& Yeoh, B. S. A. (1996). Ties that Bind: State Policy and Migrant Female Domestic Helpers in Singapore. Geoforum, 27(4), 479-493.

Hussin, S. H., \& Taibi, M. (2007). Persepsi Pembantu Rumah Wanita Warga Indonesia Terhadap Majikan di Malaysia : Kajian Kes di Bandaraya Kuching, Sarawak. [Perception of Indonesian Maids toward Employers in Malaysia: A Case Study in Kuching, Sarawak]. Retrieved from https://ir.unimas.my

Ip, H. M., Cheung, S. K., McBride-Chang, C., \& Chang, L. (2008). Associations of warmth and control of Filipina domestic helpers and mothers to Hong Kong kindergarten children's social competence. Early Education and Development, 19(2), 284-301.

Jabbar, S. K. A. (2014). The Impact of Foreign Housemaids on the Children of Working Mothers: A Case Study from Jordan. Education, 135(1), 59-68.

Kwan, N., \& Dunworth, K. (2016). English as a lingua franca communication between domestic helpers and employers in Hong Kong: A study of pragmatic strategies. English for Specific Purposes, 43, 13-24.

Lan, P. C. (2003). Maid or Madam? Filipina Migrant Workers and the Continuity of Domestic Labor. Gender and Society, 17(2), 187-208.

Lan, P. C. (2010). "They Have More Money but I Speak Better English!” Transnational Encounters between Filipina Domestics and Taiwanese Employers ). Identities: Global Studies in Culture and Power, 10(2003), 133-161.

Lee, S. S. Y. (2016). Between worlds: Filipino domestic workers in Hong Kong, 1970 - 2005. University of London.

Leong, T. P. (2011). The Economic Impacts of Migrant Maids in Malaysia. The University of Waikato.

Leung, A. H.-C. (2012). Bad influence? - an investigation into the purported negative influence of foreign domestic helpers on children's second language English acquisition. Journal of Multilingual and Multicultural Development, 33(2), 133-148.

Luk, D. M., \& Shaffer, M. A. (2005). Work and family domain stressors and support: Within- and cross-domain influences on work-family conflict. Journal of Occupational and Organizational Psychology, 78(4), 489-508. http://doi.org/10.1348/096317905X26741

Maksum, A., \& Surwandono. (2017). Suffer to survive : The Indonesian illegal workers experiences in Malaysia and Japan. Journal of Social Research \& Policy, 8(1), 1-23.

Mindarti, L. I., \& Buang, A. (2012). Pola kerentanan pembantu rumah tangga wanita migran dan majikan di negara penerima - Beberapa dapatan dari Lembah Klang, Selangor (The vulnerability of migrant female domestic workers and their employers in the host country - Some findings from Malaysia . Malaysia Journal of Society and Space, 8(2), 112-120.

Moras, A. (2009). The private home as a public workplace: Employing paid Domestic labor. Journal of Workplace Rights, 13(4), 377-400. 
Näre, L. (2008). Managing Households, Making Homes - a Moral Economy of Migrant Domestic and Care Work in Naples, (December).

Paitoonpong, S. (2002). Migrant Housemaids in Thailand: A Case Study, (December), 21-28.

Roumani, H. B. (2005). Maids in Arabia: the impact of maids as carers on children's social and emotional development. Journal of Early Childhood Research, 3(2), 149-167.

Ruijter, E. De., \& Lippe, T. van der. (2015). Getting Outside Help: How Trust Problems Explain Household Differences in Domestic Outsourcing in the Netherlands Esther. Journal of Family Issues, 30(1), 3-27.

Shah, N., Badr, H., \& Shah, M. (2012). Foreign live-in domestic workers as caretakers of older Kuwaiti men and women: socio-demographic and health correlates. Ageing and Society, 32(May 2012), 1008-1029.

Tang, S. H. K., \& Yung, L. C. W. (2016). Maids or mentors ? The effects of live-in foreign domestic workers on children's educational achievement in Hong Kong. Education Economics, 24(1), 96-230.

Tse, S. K., Lam, R. Y. H., Loh, E. K. Y., Ip, O. K. M., Lam, J. W. I., \& Chan, Y. M. (2009). EnglishSpeaking Foreign Domestic Helpers and Students' English Reading Attainment in Hong Kong. Chinese Education \& Society, 42(3), 49-65.

Van der Lippe, T., Frey, V., \& Tsvetkova, M. (2013). Outsourcing of Domestic Tasks: A Matter of Preferences? Journal of Family Issues, 34(12), 1574-1597. 